\title{
Long-lasting effects of unplanned logging on the seed rain of mixed conifer-hardwood forests in southern South America
}

\author{
Alexandre F. Souza ${ }^{1}$ Angela Luciana de Ávila ${ }^{2}$ • \\ Maristela M. Araújo ${ }^{3} \cdot$ Solon Jonas Longhi ${ }^{3}$
}

Received: 7 May 2020 / Accepted: 26 July 2020 / Published online: 26 August 2020

(C) The Author(s) 2020

\begin{abstract}
Understanding the effects of disturbance on seed rain is critical to predict changes in forest species composition and diversity. Logging effects on seed rain in a mixed conifer-hardwood forest complex in southern Brazil were evaluated. One year of seed rain data were collected from a large-scale observational experiment in logged and protected forests and quantity and average seed size weighted by species abundance (CWM) were compared between old-growth and logged stands 55 years after logging activities. Using these data, variations in frequency of functional groups of species in the seed rain were examined to see if they could be attributed to logging. Results show that the number of seeds per trap was highly right-skewed, ranging
\end{abstract}

Project funding: The work was supported by the Brazilian National Council of Technological and Scientific Development (CNPq) through the "ProjetoEcológico de Longa Duração Conservação e Manejo Sustentávelde Ecossistemas FlorestaisBioma Araucária e suas Transições" (1999-2009) and through a Master degree scholarship to Angela Luciana de Avila.

The online version is available at https://www.springerlink.com.

Electronic supplementary material The online version of this article (https://doi.org/10.1007/s11676-020-01205-8) contains supplementary material, which is available to authorized users.

Alexandre F. Souza

alexsouza.cb.ufrn.br@gmail.com

1 Departament of Ecology, CB, Rio Grande Do Norte Federal University, Central Campus, Lagoa Nova, Natal 59072-970, RN, Brazil

2 Forest Growth Department, Freiburg Im Breisgau, Baden-Vurtemberga Forest Research Institute, Wonnhaldestraße 4, Freiburg im Breisgau 79104, Germany

3 Forest Engineering Postgraduate Program, Forestry Department, Santa Maria Federal University, Roraima Av., s/n, Camobi, Santa Maria 97105-900, RS, Brazil from 13 to 12,788 seeds per trap in one year. Seed rain was affected by logging history, with seed traps in old-growth plots receiving significantly less seeds than traps in logged plots. All species included mean seed size weighted by species abundance were significantly smaller in logged than in old-growth forests. This difference persisted after the exclusion of Araucaria angustifolia, a large-seeded pioneer which was intensively logged, although the difference of seed size between the two forest classes was greatly reduced. Species abundance in the seed rain differed significantly from the established tree community, between logged and oldgrowth stands. The composition of the seed rain was much more variable than the composition of the established tree community and its points more scattered over the ordination space than the points corresponding to the protected forests. The number of collected seeds across different functional groups of species significantly differed between logged and old-growth plots. The seed rain of logged forests reflects their arrested succession as indicated by reduced abundance of functional groups such as pioneers, large seeded pioneers and Araucaria, as well as reduced functional diversity. Seed rain differences between logged and old- growth stands reflect the intensive logging of $A$. angustifolia.

Keywords Arrested succession $\cdot$ Brazil $\cdot$ Logging $\cdot$ Longlived pioneers $\cdot$ Seed rain

\section{Introduction}

Although selective logging without professional planning represents a much less degrading economic activity than deforestation, its long-term effects are only beginning to be addressed (Medjibe et al. 2013; Nuñez et al. 2019). These effects have prevailed in vast forested regions accessible by 
human settlements while demand for specific timber species existed (Gerwing 2002). Selective logging changes forest structure and species composition (Sist and NguyenThé 2002; Souza et al. 2012; Medjibe et al. 2013; Avila et al. 2015), and its effects on ecosystems have not been fully examined (Gourlet-Fleury et al. 2013). The response of trees to disturbance occurs on timescales usually larger than the duration of most ecological studies (Gourlet-Fleury et al. 2013; Edwards et al. 2014), and changes in ecosystem functions like seed dispersion and seed rain may persist long after the disturbance (Edwards et al. 2014).

Seed rain is a key process for forest structure and regeneration, and determines the demographic potential of populations (Harms et al. 2000; Hardesty and Parker 2003). The processes occurring during the early stages of a plant's life play a major role in population dynamics (Coomes and Grubb 2003; Schupp et al. 2010) and the maintenance of seed consumers (Cademartori et al. 2004; Jansen et al. 2012). During these early stages, plants experience their highest mortality and may change their spatial location through seed dispersal, including long-distance dispersal (Jones and Muller-Landau 2008). Seed dispersal influences recruitment by changing the biotic and abiotic factors surrounding seeds (Schupp et al. 2010) and by shaping species associations (Wright et al. 2016). Seed dispersal also contributes with species coexistence through the tradeoff between colonization and dispersal abilities, and by reducing competitive exclusion through dispersal limitation (Nathan and Muller-Landau 2000; Coomes and Grubb 2003). The net effect of all these seed-related phenomena is that the seed rain is a key process in determining the composition of the future forest (Harms et al. 2000; Hardesty and Parker 2003).

Disturbances to forest ecosystems such as logging may alter patterns of seed rain due to changes in the behavior of seed dispersers and can affect forest successional trajectories. For example, bird species typical of old-growth forests may preferentially disperse seeds to closed canopy vegetation due to avoidance of areas with more open canopies (Jordano and Schupp 2000), while monkeys may avoid disturbed areas if their preferred feeding trees have been removed, since they disperse seeds mostly along their major ranging routes and close to or under feeding trees (Estrada and Coates-Estrada 1984; McConkey 2000). Dispersal failure impacts tree community composition by decreasing establishment distance from parent trees (Bleher and Böhning-Gaese 2001) and increasing competition at later life stages (Nathan and Muller-Landau 2000). Despite its conservation advantages (Edwards et al. 2014), selective logging frequently targets large old trees that contribute a disproportionately high fraction of the total seed output in forest communities (Lindenmayer and Laurance 2017). Seed production is also potentially reduced through residual damage to remaining trees (GourletFleury et al. 2013) and impacts on seed-dispersing animal assemblages (Silva Matos and Watkinson 1998, 2011; Poulsen et al. 2013). Timber extraction of tree species targeted by unregulated selective logging can have profound effects on seed sources and seed rain. Understanding the effects of disturbances on the seed rain is critical to predict changes in forest species composition and diversity.

Analyses of species traits allow for the functional description of communities and have been recognized as key to a more complete understanding of the processes that shape seed rain and recruitment in tropical and subtropical forests (Jackson 1981). The functional profile of seed rain may be influenced by the structure of the tree community in complex ways. The disturbance caused by timber extraction creates canopy gaps that trigger small scale forest succession, the trajectory of which is mostly directed by the distribution of functional traits across species (Lohbeck et al. 2014; Muscolo et al. 2014). Both plant height and seed size are known to mediate the spatial extension of seed dispersal (Jackson 1981; Thomson et al. 2011), which has disproportionally strong effects on dispersal limitation of dioecious species relative to monoecious ones (Heilbuth et al. 2007). Although the long-term effects of logging on functional forest structure are poorly known, selective logging may alter the seed rain through changes in forest trait distribution (Both et al. 2019), the collapse of logged populations (Ter Steege et al. 2002), and arrested succession (Chazdon 2003; Souza et al. 2012; Edwards et al. 2014; Pyles et al. 2018; Souza and Longhi 2019).

To evaluate the effects of logging on seed rain and its functional structure in a mixed conifer-hardwood forest complex in southern South America, one year of seedfall data was collected from a large-scale observational experiment in previously logged and protected forests in southern Brazil. The dominant conifer, Araucaria angustifolia (Bertol.) Kuntze in the forests we studied is critically endangered, and the mixed forests themselves are endangered due to logging and land use change (Souza et al. 2012). The abundance and community weighted seed size were compared between old-growth stands and logged stands 55 years after the last logging activities. By assigning the species to functional groups, it was possible to detect functional changes in the seed rain associated with logging. Functional groups were defined as ecological groups of tree species that present different sets of morphological traits like wood density, leaf size, specific leaf area, and height, among others. It was hypothesized that the abundance, seed size, and functional distribution of the seed rain would be sensitive to logging even decades after timber extraction activities ended. 


\section{Materials and methods}

\section{Study area and data collection}

The study area was located in the São Francisco de Paula National Forest, Rio Grande do Sul state, southern Brazil $\left(29^{\circ} 25^{\prime} \mathrm{S}, 50^{\circ} 23^{\prime} \mathrm{W}\right)$ in the diversity-rich mixed Atlantic forests and represent a floristic transition between the tropical flora of eastern South America and the temperate flora of the southern parts of the continent (Eastern Mixed Forests sensu Gonçalves and Souza 2014). Description of the forest communities in the study area can be found in Araujo et al. (2010) and Souza et al. (2012). Mixed Atlantic forests are dominated by the long-lived pioneer conifer A. angustifolia, which establishes in grasslands, forest edges, and multiple treefall gaps, but fails to reach maturity under the closed canopy formed by angiosperms (Souza 2007, 2017; Souza et al. 2008). Araucaria produces copious crops of large edible seeds (Mantovani et al. 2004). Araucarias were the main timber species exploited in southern Brazil during the twentieth century (Cabral and Cesco 2008). The São Francisco de Paula National Forest of 1,600 ha harbors most of the tree diversity present in the landscape which has been heavily logged and grazed (Souza et al. 2012) The National Forest is a sustainable use conservation unit and displays a heterogeneous mosaic landscape of remnants of the Mixed Atlantic forests together with managed tree monocultures of A. angustifolia, and the exotics Pinus taeda L., Pinus elliottii Engelm., and Eucalyptus saligna Sm. (Fonseca et al. 2009). The National Forest and its surroundings are inhabited by large frugivorous or seed eater birds like guans (Penelope obscura Temminck) and tinamous (Tinamus solitarius Vieillot) and mammals like coatis (Nasua nasua L.) and howler monkeys (Alouatta guariba Huumboldt) (Fialho 2007), as well as by a diverse array of small frugivorous bird species (Dos Santos and Cademartori 2015). The climate is humid subtropical Köppen-Geiger $\mathrm{Cfb}$, with temperate summers and no true dry season (Alvares et al. 2013). Mean annual rainfall is $2,252 \mathrm{~mm}$ and monthly temperatures are $<15{ }^{\circ} \mathrm{C}$ for up to 8 months per year. The altitude is ca. $900 \mathrm{~m}$ and soils are derived from volcanic rocks. São Francisco de Paula has experienced increasing summer minimum temperatures and rainfall in the twentieth century (Souza and Longhi 2019). The region also experiences strong El NiñoSouthern Oscillation effects, with excess rain and increased temperatures during El Niño years, and droughts and cooler temperatures during La Niña years (Garreaud et al. 2009).

Data were collected in 2006, a weak La Niña year (https ://ggweather.com/enso/oni.htm), in six $100 \mathrm{~m} \times 100 \mathrm{~m}$ (1 ha) plots. Three of the study plots had never been logged (hereafter referred to as old-growth plots), while the other plots were subjected to unregulated selective logging of Araucaria and other unrecorded species until 1955 or 1987 (hereafter referred to as logged plots). The plots were part of a larger project on forest structure and dynamics that lasted from 1999 to 2009. At present, basal area averages $43.3 \mathrm{~m}^{2} \mathrm{ha}^{-1}$ and does not differ between logged and unlogged stands, but tree density is higher in old-growth (average 42.5 trees $\mathrm{ha}^{-1}$ ) than in logged forests (average 28.8 trees ha ${ }^{-1}$ ), as is canopy height (average $13.2 \mathrm{~m}$ in old-growth and $11.7 \mathrm{~m}$ in logged stands) (Souza et al. 2012). A total of 156 tree species were found in the study plots, which showed only minor abundance changes over nine annual census intervals, with recurrent regeneration failure of $A$. angustifolia and other long-lived pioneers in logged stands (Souza and Longhi 2019). Plots were permanent and the choice of their location was limited so as to avoid steep slopes and water courses, and were thus physiographically similar; their main differences were related to logging history (Souza et al. 2012). In 1999-2000, all trees with $\mathrm{dbh} \geq 9.5 \mathrm{~cm}$ were tagged, identified to species level and remeasured for survival, and ingrowth (new trees with $\mathrm{dbh} \geq 9.5 \mathrm{~cm}$ ) and dbh measured annually from 2001 to 2009 . To evaluate seed rain onto the plots, we installed a grid of $16 \mathrm{~m}^{2} \times 1.0 \mathrm{~m}^{2}$ seed traps in the geographic center of each of the 1.0-ha plots. The traps were plastic window screening supported on PVC frames, suspended $1-\mathrm{m}$ above the ground and located at $20 \mathrm{~m}$ intervals in a square grid and were collected every month for one year. Trap contents were separated into intact seeds, leaves, twigs, fruits, and unidentifiable material. Apparent viable seeds $>1 \mathrm{~mm}$ were counted. Taxonomic identification to the species level was achieved through consultation of the literature (Lorenzi 1992; Marchiori and Sobral 1997; Backes and Irgang 2002), and through comparisons with the seed collection of the Bolsa de Sementes project which keeps seeds collected from identified trees in the study plots. A description of the tree regeneration at the study site, seed rain included, can be found in Chami et al. (2011).

\section{Data analysis}

All analyses were carried out in R 3.6.1 (2017). With regards to seed rain differences between management histories, preliminary tests indicated that a Poisson mixed model using plots as blocks improved results (smaller AICc) over a simple Poisson Generalized Linear Model (GLM), and that spatial autocorrelation was present (Moran's I correlogram). A Generalized Estimation Equations (GEE) was then used to model the effect of logging history on seed rain variations between traps with Poisson distribution as the error structure, taking plot as a random factor and an autoregressive spatial correlation structure (Zuur et al. 2009). For this, the geelm function of the geepack package (Yan 2002) was employed. Seed size is an important feature of seed output and has a number of effects on ecosystem functioning and the interaction with dispersers and predators. 
The distribution of seed size was incorporated using seed length as a proxy. Seed rain of logged stands was compared to old-growth stands using seed abundance and using the community weighted mean seed length (CWM, mean seed length weighted by the number of seeds per species). The CWM weighs the seed length values by the abundance of each species in each trap. This was done for 35 species for which there was seed length data (see Forgiarini et al. 2015 for sampling details). We therefore used previously determined seed length data to generate CWM mean seed length per trap. The CWM was calculated using the FD package (Laliberté and Legendre 2010). The CWM is the mean seed length across species found in the seed traps weighted by the number of seeds found in each species. It thus reflects more the seed lengths of the most abundant species and less of the rarest species, depicting the dominant profile of the seed length in the sampled community (see Lavorel et al. 2008 for a detailed description). We do not have data on seed production for each species in the plots because an assessment of the fecundity of the species does not exist for the majority of the 156 species in the study area. Clustering the species into functional groups greatly aids in the interpretation of the results since the overall behavior of the ecological species groups is well-known from the literature. Analysis was done at more than one level. First an overall analysis of the brute number of seeds was determined and then a description of the species found in the seed rain, and lastly the analysis of functional groups. By approaching the data from these three sides, we provide a more complete perspective of the seed rain in the study forests. The CWM is a standard way to measure seed size because it weights the size of the seeds by the abundance of each species in the community and thus is a more reliable measure of average seed size than a crude average.

Logging history effects were assessed on seed length CWM through a GLM with Gamma error family (Zuur et al. 2009), after discarding an alternative mixed model incorporating plot as a hierarchical level (this yielded smaller AICc: 102.97 versus 107.14). The GLM was fit with the glm function of the R base package. A Moran's I correlogram revealed no spatial structure in the residuals. The same test on seed length CWM was also carried out, excluding Araucaria. By repeating the analysis without Araucaria, we could assess whether any differences in the seed length CWM occurred also among the angiosperms or were due to the presence of Araucaria in the analysis. Additionally, a G-test run with the GTest function of the DescTools package was used to test whether different functional groups and logging histories affected differences in the frequency of occurrence of seed count.

The composition relationships between seed traps and established trees in permanent plots, (species relative density of trees versus the relative density of the seeds of the same species), were assessed through a two-dimensional Non-Metric Multidimensional Scaling (NMDS) ordination. The NMDS reveals similarities between data points representing seed species in the seed traps or tree communities in the forest plots. It is an iterative search for the best positions of (in this case) seed or tree species or functional group data on $\mathrm{k}$ dimensions that minimizes the difference between original dissimilarity matrix and the ordination space. It also avoids the assumption of linear relationships among variables, allows the use of any distance measure and use ranked distances (McCune and Grace 2002). The NMDS was run on data standardized to proportions of total individuals per sampling unit using the Bray-Curtis dissimilarity, and with the metaMDS function in the 'vegan' package (options center $=\mathrm{T}$ and trymax $=10,000$ ). A separate NMDS was run on the relative abundances of ecological groups detected by Souza et al. (2014), who statistically identified six functional groups of tree species in the sampled communities based on trait data. They are: Araucaria, pioneer (fast-growing, light demanding, small-seeded), large seeded pioneer (fastgrowing, light demanding, large-seeded), wind-dispersed large trees (tall trees, slow growing, wind-dispersed trees), large shade tolerant (tall trees, shade tolerant, slow growing), and small shade tolerant (slow growing, shade tolerant treelets). Species in the seed rain that could not be ascribed to one of these groups were not included in the functional group analyses but entered into the species-level analyses. PERMANOVA (Anderson 2001) was used to test for the effects of community origin (established trees and seed rain) and management history (logged and old-growth) on species and functional group abundances at the 1-ha plot level. The analysis was performed using the function adonis in the 'vegan' package, with the Bray-Curtis distance and 10,000 permutations. Indicator species analysis was used to identify species in the seed rain that tended to be associated with logged or old-growth stands using function multipatt of the indicspecies package (De Cáceres and Legendre 2009).

\section{Results}

Seed rain was highly right-skewed, ranging from 13 to 12,788 seeds per trap in one year (median $=256.5$ seeds $\operatorname{trap}^{-1}$ year $^{-1}$ ). Overall seed rain was estimated at 2.57 million seeds $\mathrm{ha}^{-1}$ year $^{-1}$, a quantity that included seeds of gymnosperms, dicotyledonous and monocotyledonous trees, plus seeds possibly from lianas, herbs, epiphytes and hemiepiphytes. This overall count underestimates total seed rain because seeds $<5 \mathrm{~mm}$ could not be separated from the debris in the traps. Overall seed rain was strongly affected by logging history (GEE model, $P=0.0035$ ), with seed traps in old-growth plots receiving significantly less seed than traps in logged plots, and the spatial correlation between 
two neighboring seed traps in the same plot equaled 0.071 (Fig. 1). All species included, the community-weighted mean seed size was significantly smaller in logged than in old-growth forests (GLM, $P<0.0001$, Fig. 2a). The median community weighted mean seed length in old-growth areas $(0.68 \mathrm{~cm})$ was much higher than in the logged ones $(0.42 \mathrm{~cm})$. It remained smaller in logged areas compared to old-growth stands after the exclusion of Araucaria (GLM, log-transformed values, $P=0.003$ ), but the difference

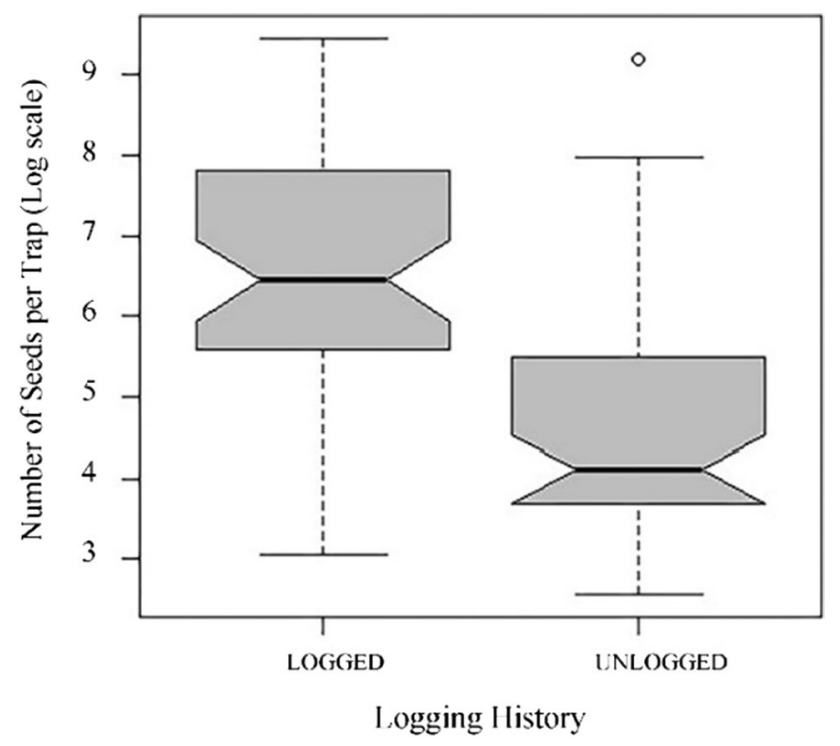

Fig. 1 Box-plots of seed rain at the São Francisco de Paula National Forest; each box comprises $50 \%$ of data and are narrowed at the median point and return to full width at the lower and upper $95 \%$ confidence interval values; circles are outliers but kept in the analyses. The $y$-axis is on a natural logarithm scale between seed rain in the two stand histories was greatly reduced (Fig. 2b). Excluding Araucarias, the median CWM seed length in old-growth areas $(0.49 \mathrm{~cm})$ was still larger than in logged areas $(0.39 \mathrm{~cm})$.

Overall, 81 species belonging to 46 genera and 28 families were recorded in all seed traps over one year (Table S1). Of these, 52 could be identified to species level. The most common families were Myrtaceae, Fabaceae, Sapindaceae, and Lauraceae. The most abundant species in the seed rain were Ilex brevicuspis Reissek, Blepharocalyx salicifolius (Kunth) O. Berg, Ilex paraguariensis A. St.-Hil., and Vernonanthura discolor (Spreng.) H. Rob., accounting for 83\% of the total seed rain. Of the species for which dispersal syndromes could be determined (72\%), $45 \%$ were animaldispersed, $27 \%$ were wind-dispersed. A total of 21 species were collected in the seed traps that were not present as marked trees in the permanent plots. These were mostly native trees but included four vines (Anchietea pyrifolia A. St.-Hil., Smilax cognata Kunth, Serjania laruotteana Cambess., and Passiflora actinia Hook.), one herb (Solanum americanum Mill.) and the exotics Pinus sp. and Desmodium adscendens (Sw.) DC (see Supplementary Material for the complete list of species found in the seed rain). The new species comprised 34.1 of the total seed rain, a number that ranged from 10.8 to $68.9 \%$ between plots. The average number of species arriving at any given seed trap was 7.2 \pm 2.5 species $\mathrm{m}^{-2}$ year $^{-1}$, ranging from 2 to 14 species $\mathrm{m}^{-2}$ year $^{-1}$. The number of tree species in the 1- ha plots varied from 41 to 68 in logged plots and from 56 to 59 in old-growth plots.

The species abundance in the seed rain differed significantly from the species composition of the established tree community (PERMANOVA; $F=5.09 ; \mathrm{df}=1,8 ; P<0.0001$ ). Additionally, the species abundance of both the seed rain
Fig. 2 Box-plots of community-weighted mean seed size at the São Francisco de Paula National Forest, a Araucaria angustifolia and $\mathbf{b}$ without Araucaria angustifolia; box symbols as in Fig. 1
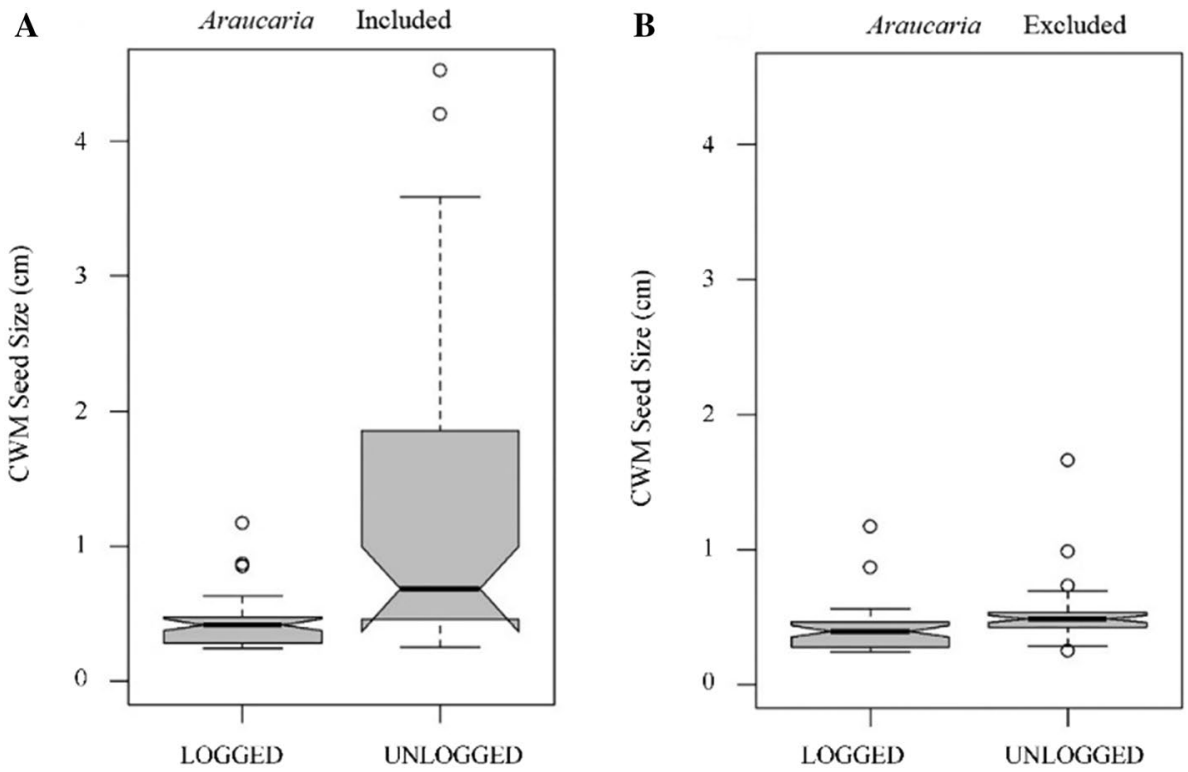
and the established tree communities differed significantly between logged and old-growth forests $(F=2.44 ; \mathrm{df}=1,8$; $p=0.025$ ). Overall, the species origin, (whether from the seed rain or from the established tree community), and management history together explained $52 \%$ of the variation in species abundance $\left(R^{2}\right)$. These results were depicted in the NMDS, in which the points corresponding to the tree communities and the seed rain were clearly separated along the first axis, with the tree communities clustered to the right and the seed rain clustered to the left (Fig. 3). Thus, the most abundant species in the tree community were not necessarily those with more seeds in the seed traps. The points corresponding to logged and old-growth areas were clustered along the second axis. The composition of the seed rain was more variable and its points more scattered over the ordination space than the points corresponding to the established tree communities.

The Indicator Species Analysis identified 21 species as indicators of the seed rain or the established tree community in logged and old-growth areas (Table S2). Seed rain distribution across different functional groups significantly differed between logged and old-growth plots (G-test, $G=56.82, \mathrm{df}=5, P<0.0001)$. The main differences were related to a reduction in the proportion of Araucaria and pioneer seed rain in logged forests, which also showed increased frequencies of large shade tolerant and winddispersed large trees (Fig. 4). The NMDS run on the abundances of the functional groups segregated the seed rain and the established tree community along the first axis (Fig. 5). The positions of the seed and tree communities in the NMDS indicates that in different communities there were different numbers of seeds or trees in each functional group, and that

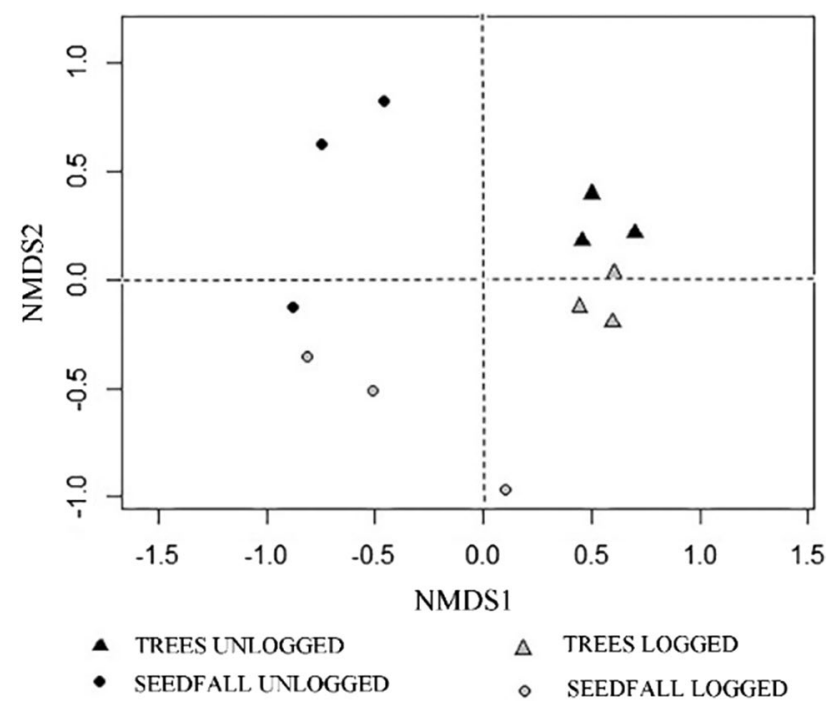

Fig. 3 Non-metric multidimensional scaling (NMDS) ordination of seed rain and forest tree communities with different management histories

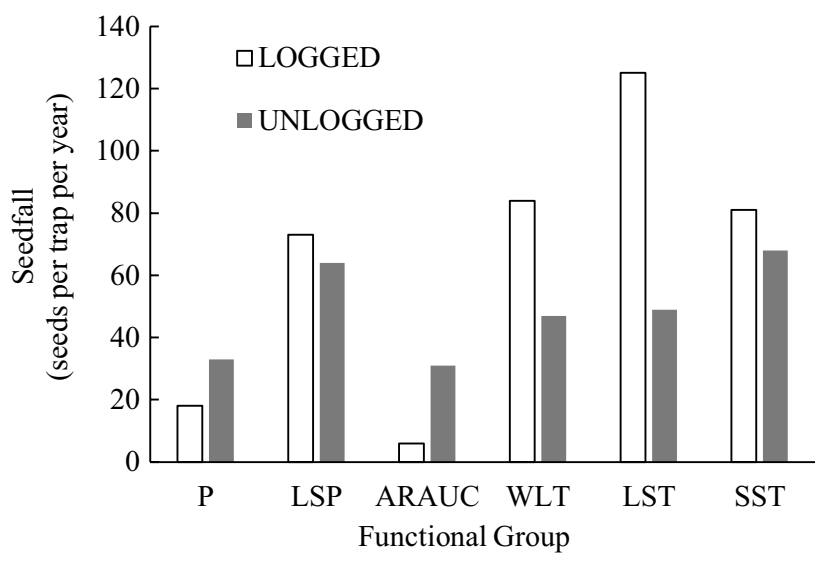

Fig. 4 Frequencies of different functional groups in the seed rain of logged and old-growth plots in the São Francisco de Paula National Forest; $P$ pioneers, $L S P$ large-seeded pioneers, ARAUC Araucaria, $W L T$ wind-dispersed large trees, $L S T$ large shade tolerant trees, and SST small shade tolerant trees

the abundance of individuals in the functional groups differed. In the established tree community, large shade tolerant species were widespread in logged stands. Araucaria, pioneers, and small shade tolerant species were prevalent among old-growth forests, while large seeded pioneers and wind-dispersed large trees prevailed in the overall seed rain. The second NMDS axis showed some plot specifics, like the prevalence of Araucaria in a single old-growth plot and the prevalence of wind-dispersed large trees in the seed rain of one logged plot.

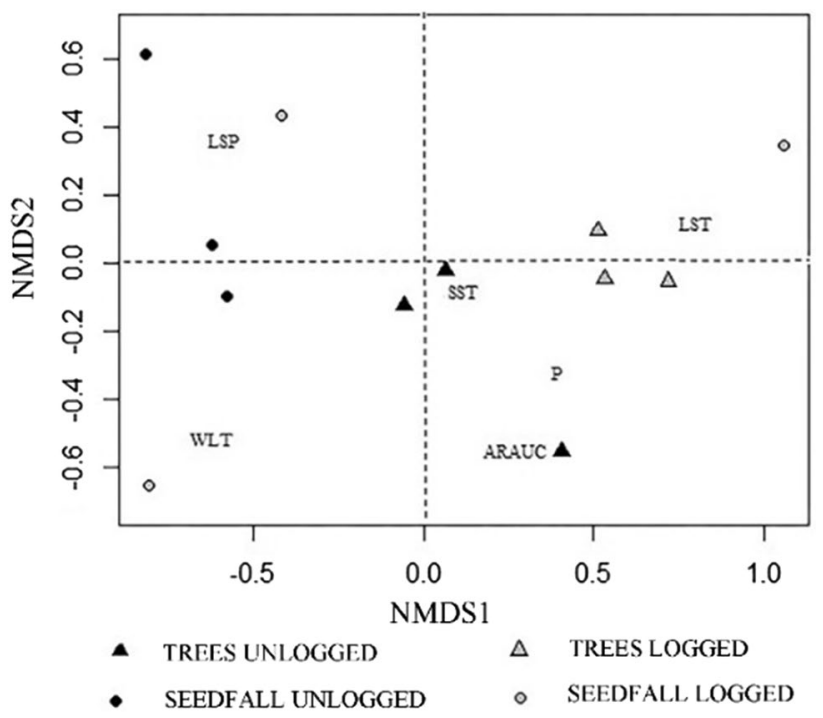

Fig. 5 Functional group non-metric multidimensional scaling (NMDS) ordination of seed rain and forest tree communities with different management histories; $P$ pioneers, $L S P$ large-seeded pioneers, $A R A U C$ Araucaria, WLT wind-dispersed large trees, $L S T$ large shade tolerant trees, and SST small shade tolerant trees 


\section{Discussion}

Our results revealed seed rain density comparable to other tropical and subtropical forests (Hardesty and Parker 2003; Poulsen et al. 2013; Capellesso et al. 2018; Terborgh et al. 2019). There were marked differences between the seed rain in logged and old-growth forests. Logged forests produced larger numbers of smaller seeds than old-growth forests because of the lack of Araucaria big seeds in seed traps of logged stands. In the Sao Francisco de Paula National Forest, logging of the largest trees resulted in logged stands being shorter with greater densities of small and dead trees (Souza et al. 2012). The logged stands are considered to be in arrested succession as indicated by Souza and Longhi (2019), and the present results indicate that this is reflected in the seed rain as well. This study has shown that logged forests in the study area showed signs of arrested succession as indicated by reduced abundances of functional groups like wind-dispersed large trees, large pioneers and Araucaria, as well as reduced functional diversity (De Avila et al. 2011; Forgiarini et al. 2015; Souza and Longhi 2019). It is possible that species in the functional groups large pioneers and wind-dispersed large trees have been responsible for the increased seed production in logged plots, while the lack of Araucaria in these plots was the main cause of their reduced overall seed size. Logged forests often result in altered light, temperature, and vegetation structure relative to old-growth forests, but these alterations seem not to have inhibited the activity of seed dispersers in logged stands (Edwards et al. 2014).

Elsewhere seed size has not been found to be much affected by selective logging (Pyles et al. 2018). However, old-growth forests in our study are dominated by large and abundant $A$. angustifolia trees (Souza 2007; Araujo et al. 2010), which produce abundant crops of large edible seeds (Mantovani et al. 2004). Araucarias were the main timber species exploited during logging operations in southern Brazil over the twentieth century (Cabral and Cesco 2008), and because of this, the species is endangered and its geographical distribution today is much reduced relative to its original area (Ribeiro et al. 2009). Araucaria is a long-lived pioneer that regenerates massively after large-scale disturbances like landslides, windthrow, and edge formation, creating dense stands where trees reach large sizes and live for centuries without successful recruitment in the shade formed by angiosperms but on disturbed sites (Klein 1960; Souza 2007; Souza et al. 2008). Despite this, Araucaria seeds are an important food source for native mammal and bird species (Vieira and Iob 2009). The massive removal of Araucaria was the main reason for the marked differences in forest structure and dynamics between the logged and old-growth forests (Araujo et al. 2010; Souza et al. 2012; Souza and Longhi 2019). As long-lived pioneers, Araucarias showed a recruitment surge into intermediate size classes after disturbance by selective logging, but failed to attain mature sizes in logged forests due to shadowing by remaining angiosperms (Souza et al. 2008; Souza and Longhi 2019). Our results indicate marked seed biomass reduction in the logged forests seed rain due to the lack of Araucaria seeds. This agrees with the finding that seed size variation indicates changes in forest height and carbon storage potential between old-growth and human-impacted forests (Osuri and Sankaran 2016). Our results should be interpreted with caution since they were limited to a single year and therefore may not capture the full complexity and diversity of species actually hitting the forest floor as seed rain. Araucaria, for instance, shows strong, and possibly random, year-to-year fluctuation in seed production (Souza et al. 2014) and the patterns in this study may show marked yearly changes.

The reduced seed biomass in logged areas due to the lack of Araucaria seeds may have considerable cascading impacts on seed eaters and seed dispersers. Araucaria seeds are produced during the winter months when communitywide seed production is lower (Paise and Vieira 2005). They are consumed by an array of at least 23 species of insects, birds and mammals (Vieira and Iob 2009). There is evidence that Araucaria seeds are a key resource for small rodent and bird seedeaters, whose abundance and distribution have been shown to be driven by Araucaria seed production (Cademartori et al. 2004; Iob and Vieira 2008; Marini et al. 2010). With the lack of regeneration of Araucaria following selective logging, both for its short-lived persistence in the soil seed bank (Gasparin et al. 2019) and for its shade intolerance (Souza et al. 2008, 2012; De Avila et al. 2011; Souza and Longhi 2019), a widespread breakdown of dispersal systems in mixed Atlantic forest remnants could be expected due to local disperser extinction driven by reduced seed biomass (Silva Matos and Watkinson 1998; Peres et al. 2015). Among other effects, dispersal failure impacts tree community composition by decreasing establishment distance from parent trees (Bleher and Böhning-Gaese 2001) and by increasing competition at later life stages (Nathan and Muller-Landau 2000). Additionally, reduced seed disperser abundances in logged forests due to the lack of Araucaria may have reinforcing effects on the ability of this conifer to re-colonize logged sites because dioecious species like Araucaria are particularly prone to failure in colonizing uninhabited sites in the case of reduced seed dispersal, despite massive seed production (Heilbuth et al. 2007). The potential selective timber logging of pre-reproductive Araucarias is an additional factor hampering the recolonization of logged stands.

Our results support the hypothesis that community assembly in southern mixed forests may occur by processes other than by the seed fall itself. Non-metric multidimensional scaling showed that the species composition of the seed rain was more variable than the composition of the established 
tree community. This is attributable in part to the haphazard arrival of individual dispersed seeds at the $1-\mathrm{m}^{2}$ scale (Terborgh et al. 2019), as well as to a mismatch between the composition of the seed rain and that of the tree community, including long-distance immigrant seed rain (Hardesty and Parker 2003; Muller-Landau et al. 2008). This pattern, together with the presence in the seed rain of species not found in the established tree community, indicates that most abiotic or biotic filters that may structure the tree community mainly act after the germination stage (however, see Wright et al. 2016). This is in agreement with De Avila et al. (2011) who found considerable similarities between the seedling bank and the mature trees, but not between the seed rain and mature trees in the same study area as ours. At the species level, this pattern indicates that even old-growth forests receive abundant seed rain of early-successional species from surrounding disturbed communities, a key coexistence process based on the colonization-competition tradeoff (Coomes and Grubb 2003). One example was the fast-growing and light demanding Vernonanthura discolor (Less.) H.Rob., once a rare species in old-growth plots but that is now frequent in the understory of disturbed forests (Chami et al. 2011) and whose light seeds were among the most abundant in the seed rain. However, in spite of differences between the highly variable seed rain and the tree community, the species composition of the seed rain reflected the main division between old-growth and logged forests. This indicates the long-lasting effects of the logging disturbance on the composition of the logged forests, the composition and activity of seed dispersers, and dispersal distances five decades after timber extraction ceased (Souza et al. 2012; Poulsen et al. 2013; Nuñez et al. 2019; Souza and Longhi 2019).

Selective logging may alter the functional structure of the seed rain through changes in forest trait distribution (Both et al. 2019), the collapse of logged populations (Ter Steege et al. 2002), and by arrested succession (Chazdon 2003; Souza et al. 2012; Edwards et al. 2014; Pyles et al. 2018). Additionally, the decreased representation of small shade tolerant species in the seed rain of logged stands may result from damage to understory vegetation during logging operations (Souza et al. 2012; Gourlet-Fleury et al. 2013; Medjibe et al. 2013). The abundance of large seeded pioneers and wind-dispersed large species in the seed rain of both logged and old-growth stands indicate that the paucity of these groups in logged forests is not attributable to the lack of immigrants but to growth and survival bottlenecks in the seed bank and seedling stages (Avila et al. 2013). Evaluating stand dynamics in southern Brazilian mixed Atlantic forests, Souza and Longhi (2019) concluded that the functional impoverishment of logged stands was due to the lack of natural regeneration of ecological groups targeted by logging, mainly long-lived pioneers like Araucaria and large seeded pioneers and wind dispersed large trees. Our results confirm this and indicate that such regeneration failure can be currently found in the seed rain. If restoration of the full representation of functional groups and their associated ecosystem services in logged, subtropical mixed Atlantic forests in southern Brazil and Argentina is desired, it will require the active management of logged stands. This is because long-lived pioneers are not likely to recover their dominance in these forests through seed rain and secondary succession.

Acknowledgements We are grateful to Régis Longhi, Marcelo Krug and Ângelo Ebling for their assistance in data collection. This research is registered in the Sistema Nacional de Gestão do Patrimônio Genético e do Conhecimento Tradicional Associado (SISGEN) under code $\mathrm{ABB} 45 \mathrm{BE}$

Open Access This article is licensed under a Creative Commons Attribution 4.0 International License, which permits use, sharing, adaptation, distribution and reproduction in any medium or format, as long as you give appropriate credit to the original author(s) and the source, provide a link to the Creative Commons licence, and indicate if changes were made. The images or other third party material in this article are included in the article's Creative Commons licence, unless indicated otherwise in a credit line to the material. If material is not included in the article's Creative Commons licence and your intended use is not permitted by statutory regulation or exceeds the permitted use, you will need to obtain permission directly from the copyright holder. To view a copy of this licence, visit http://creativecommons.org/licenses/by/4.0/.

\section{References}

Alvares CA, Stape JL, Sentelhas PC, Gonçalves JLM, Sparovek G (2013) Köppen's climate classification map for Brazil. Meteorol Zeitschrift 22:711-728. https://doi. org/10.1127/0941-2948/2013/0507

Anderson MJ (2001) A new method for non-parametric multivariate analysis of variance. Austral Ecol 26:32-46

Araujo M, Chami L, Longhi S, Avila AL, Brena DA (2010) Análise de agrupamento em remanescente de Floresta Ombrófila Mista. Ciência Florest 20:1-18

Avila A, Araujo M, Gasparin E, Longhi S (2013) Mecanismos de regeneração natural em remanescente de Floresta Ombrófila Mista, RS, Brasil. Cerne 19:621-628

Avila AL, Ruschel AR, Carvalho JOP, Mazzei L, Silva JNM, Lopes JC, Araujo MM, Dormann CF, Bauhus J (2015) Medium-term dynamics of tree species composition in response to silvicultural intervention intensities in a tropical rain forest. Biol Conserv 191:577-586. https://doi.org/10.1016/j.biocon.2015.08.004

Backes P, Irgang B (2002) Árvores do sul: guia de identificação e reconhecimento, ecológico edn. Pallotti, Porto Alegre

Bleher B, Böhning-Gaese K (2001) Consequences of frugivore diversity for seed dispersal, seedling establishment and the spatial pattern of seedlings and trees. Oecologia 129:385-394. https://doi. org/10.1007/s004420100747

Both S, Riutta T, Paine CET, Elias DMO, Cruz RS, Jain A, Johnson D, Kritzler UH, Kuntz M, Majalap-Lee N, Mielke N, Pilco MXM, Ostle NJ, The YA, Malhi Y, Burslem DRFP (2019) Logging and soil nutrients independently explain plant trait expression in tropical forests. New Phytol 221:1853-1865. https://doi.org/10.1111/ nph. 15444 
Cabral DC, Cesco S (2008) Notas para uma história da exploração madeireira na Mata Atlântica do sul-sudeste. Ambient Soc XI:33-48

Cademartori CV, Fabián ME, Menegheti JO (2004) Variações na abundância de roedores (Rodentia, Sigmodontinae) em duas áreas de floresta ombrófila mista, Rio Grande do Sul, Brasil. Rev Bras Zoociências 6:147-167

Capellesso ES, Scrovonski KL, Zanin EM, Sausen TL (2018) Relação entre chuva de sementes e estrutura florestal em remanescentes de Floresta Atlântica no Sul do Brasil. Iheringia-Ser Bot 73:176-181. https://doi.org/10.21826/2446-8231201873209

Chami LB, Araujo MM, Longhi SJ, Kielse P, Lucio ADC (2011) Mecanismos de regeneração natural em diferentes ambientes de remanescente de Floresta Ombrófila Mista, São Francisco de Paula, RS. Ciência Rural 41:251-259. https://doi.org/10.1590/ S0103-84782011000200012

Chazdon RL (2003) Tropical forest recovery: legacies of human impact and natural disturbances. Perspect Plant Ecol Evol Syst 6:51-71

Coomes DA, Grubb PJ (2003) Colonization, tolerance, competition and seed-size variation within functional groups. Trends Ecol Evol 18:283-291. https://doi.org/10.1016/S0169-5347(03)00072-7

De Avila AL, Araujo MM, Longhi SJ, Gasparin E (2011) Agrupamentos florísticos na regeneração natural em remanescente de Floresta Ombrófila Mista, RS, Brasil. Sci For 39:331-342

De Cáceres M, Legendre P (2009) Associations between species and groups of sites: indices and statistical inference. Ecology 90:3566-3574. https://doi.org/10.1890/08-1823.1

Dos Santos MFB, Cademartori CV (2015) Composição e abundância da avifauna em quatro fitofisionomias de área rural pertencente ao domínio da Mata Atlântica no sul do Brasil. Ciência Florest 25:351-361. https://doi.org/10.5902/1980509818453

Edwards DP, Tobias JA, Sheil D, Meijaard E, Laurance WF (2014) Maintaining ecosystem function and services in logged tropical forests. Trends Ecol Evol 29:511-520. https://doi.org/10.1016/j. tree.2014.07.003

Estrada A, Coates-Estrada R (1984) Fruit eating and seed dispersal by howling monkeys (Alouatta palliata) in the tropical rain forest of Los Tuxtlas, Veracruz, Mexico. Am J Primatol 6:77-91

Fialho M (2007) Riqueza e abundância da fauna de médio e grande porte em três modelos de áreas protegidas no sul do Brasil. Universidade Estadual de Campinas

Fonseca CR, Ganade G, Baldissera R, Becker CG, Boelter CR, Brescovit AD, Campos LM, Fleck T, Fonseca VS, Hartz SM, Joner F, Kaffer MI, Leal-Zanchet AM, Marcelli MP, Mesquita AS, Mondin CA, Paz CP, Petry MV, Piovensan FN, Putzke J, Stranz A, Vergara M, Vieira EM (2009) Towards an ecologically-sustainable forestry in the Atlantic Forest. Biol Conserv 142:1209-1219. https://doi. org/10.1016/j.biocon.2009.02.017

Forgiarini C, Souza AF, Longhi SJ, Oliveira JM (2015) In the lack of extreme pioneers: trait relationships and ecological strategies of 66 subtropical tree species. J Plant Ecol 8:359-367. https://doi. org/10.1093/jpe/rtu028

Garreaud RD, Vuille M, Compagnucci R, Marengo J (2009) Presentday South American climate. Palaeogeogr Palaeoclimatol Palaeoecol 281:180-195. https://doi.org/10.1016/j.palaeo.2007.10.032

Gasparin E, Faria JMR, José AC, Tonetti OAO, Melo RA, Hilhorst HWM (2019) Viability of recalcitrant Araucaria angustifolia seeds in storage and in a soil seed bank. J For Res (in press). https ://doi.org/10.1007/s11676-019-01001-z

Gerwing J (2002) Degradation of forests through logging and fire in the eastern Brazilian Amazon. For Ecol Manage 157:131-141. https ://doi.org/10.1016/S0378-1127(00)00644-7

Gonçalves E, Souza A (2014) Floristic variation in ecotonal areas: patterns, determinants and biogeographic origins of subtropical forests in South America. Austral Ecol 39:122-134. https://doi. org/10.1111/aec.12051

Gourlet-Fleury S, Mortier F, Fayolle A, Fayolle A, Baya F, Ouédraogo D, Bénédet F, Picard N (2013) Tropical forest recovery from logging: a 24 year silvicultural experiment from Central Africa. Philos Trans R Soc B Biol Sci 368:20120302. https://doi. org/10.1098/rstb.2012.0302

Gutiérrez-Granados G (2011) Effect of logging on rodent scatterhoarding dynamics in tropical forests: implications for plant recruitment. Integr Zool 6:74-80. https://doi.org/10.111 1/j.1749-4877.2011.00234.x

Hardesty BD, Parker VT (2003) Community seed rain patterns and a comparison to adult community structure in a West African tropical forest. Plant Ecol 164:49-64. https://doi.org/10.1023/A:10212 51831806

Harms KE, Wrght SJ, Calderón O, Hernández A, Herre EA (2000) Pervasive density-dependent recruitment enhances seedling diversity in a tropical forest. Nature 404:493-495

Heilbuth JC, Ilves KL, Otto SP (2007) The consequences of dioecy for seed dispersal: modeling the seed-shadow handicap. Evolution 55:880-888. https://doi.org/10.1111/j.0014-3820.2001.tb00605.x

Iob G, Vieira EM (2008) Seed predation of Araucaria angustifolia (Araucariaceae) in the Brazilian Araucaria Forest: influence of deposition site and comparative role of small and 'large' mammals. Plant Ecol 198:185-196. https://doi.org/10.1007/s1125 8-007-9394-6

Jackson JF (1981) Seed size as a correlate of temporal and spatial patterns of seed fall in a neotropical forest. Biotropica 13:121-130

Jansen PA, Hirsch BT, Emsens WJ, Zamora-Gutierrez V, Wikelski M, Kays R (2012) Thieving rodents as substitute dispersers of megafaunal seeds. Proc Natl Acad Sci 109:12610-12615. https:// doi.org/10.1073/pnas.1205184109

Jones FA, Muller-Landau HC (2008) Measuring long-distance seed dispersal in complex natural environments: an evaluation and integration of classical and genetic methods. J Ecol 96:642-652. https ://doi.org/10.1111/j.1365-2745.2008.01400.x

Jordano P, Schupp EW (2000) Seed disperser effectiveness: the quantity component and patterns of seed rain for Prunus mahaleb. Ecol Monogr 70:591-615. https://doi.org/10.2307/2657187

Klein RM (1960) O aspecto dinâmico do pinheiro brasileiro. Sellowia 12:17-51

Laliberté E, Legendre P (2010) A distance-based framework for measuring functional diversity from multiple traits. Ecology 91:299 305. https://doi.org/10.1890/08-2244.1

Lavorel S, Grigulis K, McIntyre S, Williams NSG, Garden D, Dorrough J, Berman S, Quetier F, Thebault A, Bonis A (2008) Assessing functional diversity in the field-methodology matters! Funct Ecol 22(1):134-147

Lindenmayer DB, Laurance WF (2017) The ecology, distribution, conservation and management of large old trees. Biol Rev 92:14341458. https://doi.org/10.1111/brv.12290

Lohbeck M, Poorter L, Martínez-Ramos M, Rodriguez-Velázquez J, van Breugel M, Bongers F (2014) Changing drivers of species dominance during tropical forest succession. Funct Ecol 28:10521058. https://doi.org/10.1111/1365-2435.12240

Lorenzi H (1992) Árvores brasileiras: manual de identificação e cultivo de plantas arbóreas nativas do Brasil. Plantarum, Nova Odessa

Mantovani A, Morellato LPC, Reis MS (2004) Fenologia reprodutiva e produção de sementes em Araucaria angustifolia (Bert.) $\mathrm{O}$. Kuntze Rev Bras Botânica 27:787-796

Marchiori JNC, Sobral M (1997) Dendrologia das angiospermas, Myrtales edn. da UFSM, Santa Maria

Marini MÂ, Barbet-Massin M, Martinez J, Prestes NP, Jiguet F (2010) Applying ecological niche modelling to plan conservation actions 
for the Red-spectacled Amazon (Amazona pretrei). Biol Conserv 143:102-112. https://doi.org/10.1016/j.biocon.2009.09.009

McConkey KR (2000) Primary seed shadow generated by gibbons in the rain forests of Barito Ulu, central Borneo. Am J Primatol 52:13-29. https://doi.org/10.1002/1098-2345(20000 9)52:1<13:AID-AJP2>3.0.CO;2-Y

McCune B, Grace JB (2002) Analysis of ecological communities. MJM Software, Gleneden Beach

Medjibe VP, Putz FE, Romero C (2013) Certified and uncertified logging concessions compared in gabon: changes in stand structure, tree species, and biomass. Environ Manage 51:524-540. https:// doi.org/10.1007/s00267-012-0006-4

Muller-Landau HC, Wright SJ, Calderón O, Condit R, Hubbell SP (2008) Interspecific variation in primary seed dispersal in a tropical forest. J Ecol 96:653-667. https://doi.org/10.111 1/j.1365-2745.2008.01399.x

Muscolo A, Bagnato S, Sidari M, Mercurio R (2014) A review of the roles of forest canopy gaps. J For Res 25:725-736. https://doi. org/10.1007/s11676-014-0521-7

Nathan R, Muller-Landau HC (2000) Spatial patterns of seed dispersal, their determinants and consequences for recruitment. Trends Ecol Evol 15:278-284

Nuñez CL, Clark JS, Clark CJ, Poulsen JR (2019) Low-intensity logging and hunting have long-term effects on seed dispersal but not fecundity in Afrotropical forests. AoB Plants 11(1). https://doi. org/10.1093/aobpla/ply074

Osuri AM, Sankaran M (2016) Seed size predicts community composition and carbon storage potential of tree communities in rain forest fragments in India's Western Ghats. J Appl Ecol 53:837-845. https://doi.org/10.1111/1365-2664.12626

Paise G, Vieira EM (2005) Produção de frutos e distribuição espacial de angiospermas com frutos zoocóricos em uma Floresta Ombrófila Mista no Rio Grande do Sul, Brasil. Rev Bras Botânica 28:615-625

Peres CA, Thaise E, Schietti J, Desmoulieres SJM, Levi T (2015) Dispersal limitation induces long-term biomass collapse in overhunted Amazonian forests. Proc Natl Acad Sci USA 113:892-897. https://doi.org/10.1073/pnas.1516525113

Poulsen JR, Clark CJ, Palmer TM (2013) Ecological erosion of an Afrotropical forest and potential consequences for tree recruitment and forest biomass. Biol Conserv 163:122-130. https://doi. org/10.1016/j.biocon.2013.03.021

Pyles MV, Prado-Junior JA, Magnago LFS, de Paula A, Meira-Neto JAA (2018) Loss of biodiversity and shifts in aboveground biomass drivers in tropical rainforests with different disturbance histories. Biodivers Conserv 27:3215-3231. https://doi.org/10.1007/ s10531-018-1598-7

R-Core-Team (2017) R: A language and environment for statistical computing. Version 3(4):3

Ribeiro MC, Metzger JP, Martensen AC, Ponzoni FJ, Hirota MM (2009) The Brazilian atlantic forest: How much is left, and how is the remaining forest distributed? Implications for conservation. Biol Conserv 142:1141-1153

Schupp EW, Jordano P, Gómez JM (2010) Seed dispersal effectiveness revisited: a conceptual review. New Phytol 188:333-353. https:// doi.org/10.1111/j.1469-8137.2010.03402.x

Silva Matos DM, Watkinson AR (1998) The fecundity, seed, and seedling ecology of the edible palm Euterpe edulis in southeastern Brazil. Biotropica 30:595-603
Sist P, Nguyen-Thé N (2002) Logging damage and the subsequent dynamics of a dipterocarp forest in East Kalimantan (1990-1996). For Ecol Manage 165:85-103. https://doi.org/10.1016/S0378 -1127(01)00649-1

Souza AF, Forgiarini C, Longhi SJ, Oliveira JM (2014) Detecting ecological groups from traits: a classification of subtropical tree species based on ecological strategies. Brazilian J Bot 37:441-452. https://doi.org/10.1007/s40415-014-0084-z

Souza AF (2007) Ecological interpretation of multiple population size structures in trees: The case of Araucaria angustifolia in South America. Austral Ecol 32:524-533. https://doi.org/10.11 11/j.1442-9993.2007.01724.x

Souza AF (2017) Conifer demography in forest-grassland mosaics: a landscape-scale study over a 24-year period. Botany 95:717-729. https://doi.org/10.1139/cjb-2016-0315

Souza AF, Cortez LSR, Longhi SJ (2012) Native forest management in subtropical South America: long-term effects of logging and multiple-use on forest structure and diversity. Biodivers Conserv 21:1953-1969. https://doi.org/10.1007/s10531-012-0287-1

Souza AF, Forgiarini C, Longhi SJ, Brena DA (2008) Regeneration patterns of a long-lived dominant conifer and the effects of logging in southern South America. Acta Oecologica 34:221-232. https ://doi.org/10.1016/j.actao.2008.05.013

Souza AF, Longhi SJ (2019) Disturbance history mediates climate change effects on subtropical forest biomass and dynamics. Ecol Evol 00:ece3.5289-ece3.5289. https://doi.org/10.1002/ece3.5289

Ter Steege H, Welch I, Zagt R (2002) Long-term effect of timber harvesting in the Bartica Triangle, Central Guyana. For Ecol Manage 170:127-144. https://doi.org/10.1016/S0378-1127(01)00777-0

Terborgh J, Zhu K, Loayza PA, Valverde FC (2019) Seed limitation in an Amazonian floodplain forest. Ecology 100:e02642. https:// doi.org/10.1002/ecy.2642

Thomson FJ, Moles AT, Auld TD, Kingsford RT (2011) Seed dispersal distance is more strongly correlated with plant height than with seed mass. J Ecol 99:1299-1307. https://doi.org/10.111 1/j.1365-2745.2011.01867.x

Vieira EM, Iob G (2009) Dispersão e predação de sementes de Araucaria angustifolia. In: Fonseca CR, Souza AF, Leal-Zanchet AM, et al. (eds) Floresta com Araucária: Ecologia, Conservação e Desenvolvimento Sustentável. Holos, Ribeirão Preto, pp 85-96

Wright SJ, Calderón O, Hernandéz A, Detto M, Jansen PA (2016) Interspecific associations in seed arrival and seedling recruitment in a Neotropical forest. Ecology 97:2780-2790. https://doi. org/10.1002/ecy.1519

Yan J (2002) geepack: yet another package for Generalized Estimating Equations. R News 2(3):12-14

Zuur AF, Ieno EN, Walker N, Saveliev AA, Smith GM (2009) Mixed effects models and extensions in ecology with R. Springer, New York

Publisher's Note Springer Nature remains neutral with regard to jurisdictional claims in published maps and institutional affiliations. 